EICHE, V.: Cold damage and plant mortality in experimental provenance plantations with Scots pine in northern Sweden. Studia For. Suec. 36 219 pp. (1966). - ERIKSSON, G.: Evolutionary forces influencing variation among populations of Pinus sylvestris. Silva Fenn. 32: 173-184 (1998). - ERIKSSON, G. and EkBERG, I.: An introduction to forest genetics. SLU, Uppsala, 166 pp. ISBN 91-576-6032-8 (2001). — GIANOLA, D. and Norton, H. W.: Scaling threshold characters. Genetics 99: 357-364 (1981). - GUllberG, U. and Vegerfors, B.: Genotype-environmen interaction in Swedish material of Pinus sylvestris. Scand. J. For. Res. 2: 417-432 (1987). - HAAPANEN, M.: Impact of family-by-trial interaction on utility of progeny testing methods for Scots pine. Silvae Genet. 45, 130-135 (1996). - HAAPANEN, M.: Time trends in genetic paramete estimates and selection efficiency for Scots pine in relation to field testing method. For. Genet. 8, 129-144 (2001). - HeIDE, O. M.: Physiological aspects of climatic adaptation in plants with special reference to high-latitude environments. In: KAURIN, A., JUNTTILA, O. and NILSEN, J. (eds): Plant production in the north, pp. 1-22. Norwegian University Press, Oslo. ISBN 82-00-07385-8 (1985). - HÄNNINEN, H., BEukeR, E. Johnsen, Ø., Leinonen, I., Murray, M., Sheppard, L. and Skrøppa, T. Impacts of climate change on cold hardiness of conifers. In: BIGRAS, F and Colombo, S., (eds): Conifer cold hardiness, pp. 305-333. Kluwer Academic Publishers, Dordrecht. ISBN 0-7923-6636-0 (2001). - JANSSON, G., LI, B. and Hannrup, B.: Time trends in genetic parameters for height and optimal age forparental selection in Scots pine. For. Sci. 49 (5): 696-705 (2003). - JAnsson, G., DAnell, Ö. and Stener, L.-G. Correspondence between single-tree and multiple-tree plot genetic tests for production traits in Pinus sylvestris. Can. J. For. Res. 28, 450-458 (1998). - JunTtILA, O.: Plant adaptation to temperature and photoperiod. Agricultural and food science in Finland 5: 251-260 (1996). KoskI, V.: Breeding plans in case of global warming. Euphytica 92 (1-2) 235-239 (1996). - LINDGREN, D.: Prediction and optimization of genetic gain with regard to genotype $\mathrm{x}$ environment interactions. Studia Forestalia Suecia. (166) pp 15-24 (1982). — LocKWOOD, J. G.: World Climatic Systems, 292 pp. Edward Arnold Ltd, London. ISBN 0-7131-6404-2 (1985). - MATYAS, C.: Modeling climate change effects with provenance test data. Tree Physiology 14: 797-804 (1994). - MoRÉN, A. S. and PERTTU, K. L.: Regional temperature and radiation indices and their adjustment to horizontal and inclined forest land. Stud. For. Suec. 194 19 pp. (1994). - NeKRASOV, V. I.: The concept of forest genetic improvement in Russia. Lesovedenie. 5:3-7. (in Russian) (1995). - New, M. Lister, D., Hulme, M. and MAKIN, I.: A high-resolution data set of surface climate over global land areas. Clim. Res. 21: 1-25 (2002). - Nilsson J. E.: Variation in early winter hardening within families of Pinus sylvestris (L.) from northern Sweden. Scand. J. For. Res. 5: 17-27 (1990). -
NILSSON J. E.: Seasonal changes in phenological traits and cold hardiness of F1-populations from plus-trees of Pinus sylvestris and Pinus con torta of various geographical origins. Scand. J. For. Res. 16: 7-20 (2001) - Nilsson, J.-E. and ANDERsson, B.: Performance in freezing tests and field experiments of full-sib families of Pinus sylvestris (L.). Can. J. For. Res. 17, 1340-1347 (1987). - Odin, H., ERIKsson, B. and Perttu, K. Temperaturklimatkartor för svenskt skogsbruk. Rapporter i skogsekologi och skoglig marklära 45, Inst. för skoglig marklära, SLU, 57 pp. Uppsala. ISBN 91-576-1644-2. In Swedish. (1983). - PERSSON, B.: Effects of provenance transfer on survival in nine experimental series with Scots pine (Pinus sylvestris L.) Scand. J. For. Res. 9: 275-287 (1994). — PERSSON, T. and ANDERSSON, B.: Genetic variance and covariance patterns of growth and survival in northern Pinus sylvestris. Scand. J. For. Res. 18: 332-343 (2003). - Persson, B. and Stahl, E.: Survival and yield of Pinus sylvestris L. as related to provenance transfer and spacing at high altitudes in northern Sweden. Scand. J. For. Res. 5: 381-395 (1990). Räisänen, J., Hansson, U., Ullerstig, A., Dösher, R., Graham, L. P., Jones, C., Meier, M., Samuelsson, P. and Willén, U.: GCM driven simulations of recent and future climate with the Rossby centre coupled atmosphere - Baltic Sea regional climate model RCAO. SMHI, Reports Meteorology and Climatology. No 101. 61 p (2003). — Rosvall, O., JansSON, G., ANDERsson, B., Ericsson, T, Karlsson, B. SONEsson, J. and Stener, L.-G.: Predicted genetic gain from existing and future seed orchards and clone mixes in Sweden. In: HaApanen, M. and Mikola, J. (eds.): Integrating tree breeding and forestry, pp. 71-85. Finnish Forest Research Institute, Vantaa. ISBN 951-40-1822-2 (2002). — SAVOLAINEN, O. A. and Hurme, P. K.: Conifers from the cold. In: BiJlsma, R. and LOESCHCKE, V. (eds): Environmental stress, adaptation and evolution, pp 43-62. Birkhäuser verlag, Basel, Swizerland. ISBN 3-7643-5695-2 (1997). - SAS Institute InC.: SAS/STAT User's Guide, Version 8, Cary, NC. 3884 pp. ISBN 1-58025-494-2 (1999). — Shutyaev, A. M. and GiERTYCH, M. Height growth variation in a comprehensive Eurasian provenance experiment of (Pinus sylvestris L.). Silvae Genet. 46: 332-349 (1997). - Shutyaev, A. M. and Giertych, M.: Genetic subdivisions of the range of Scots pine (Pinus sylvestris L.) based on a transcontinental provenance experiment. Silvae Genet. 49. 137-151 (2000). — SUNDBLAD, L-G. and Andersson, B.: No difference in frost hardiness between high and low altitude Pinus sylvestris (L.) offspring. Scand. J. For. Res. 10 22-26 (1995). - TigerstedT, P. M. A.: Adaptation, variation and selection in marginal areas. Euphytica 77: 171-174 (1994). - ZHELEV, P. EkBerg, I., ERIKSson, G. and NorELl, L.: Genotype environment interactions in four full-sib progeny trials of Pinus Sylvestris (L.) with varying site indices. For. Genet. 10, 93-102 (2003).

\title{
Inbreeding in Pinus Radiata - V. The Effects of Inbreeding on Fecundity
}

\author{
By H. X. Wu'1), J. V. Owen, A. AbarqueZ and A. C. Matheson
}

(Received 9 ${ }^{\text {th }}$ Juni 2004)

\begin{abstract}
A successful inbreeding and hybrid breeding strategy in tree improvement requires that 1 ) inbreeding (selfing) can produce superior inbred lines (effective purging of deleterious alleles), 2 ) there is heterosis among crosses of inbred lines, 3) early selection between lines is effective, and 4) inbreeding will not substantially reduce reproductive ability. We have previously reported that inbreeding depression on growth was lower in radiata pine relative to other conifers and segregation in the first two-generations of selfs generated superior inbred trees.
\end{abstract}

1) CSIRO Division of Forestry and Forest Products, PO Box E4008, Kingston, Canberra, ACT 2604, Australia. E-mail: Harry.Wu@csiro.au
In addition, we have observed that early selection among inbred trees (lines) was more effective than in out-crossed populations and there was an apparent heterosis in radiata pine. In this study, the effect of inbreeding on the reproductive ability in young and adult trees of radiata pine has been quantified from five populations of varied inbreeding levels $(\mathrm{F}=0,0.125$, $0.25,0.5$, and 0.75 ). It was observed that the effects of inbreeding depression on fecundity was higher at a young age than at older age and inbreeding depression at a young age is due to two factors: 1 ) a delay of reproductive age (about 8.3, and 8.5\% of trees delayed for $\mathrm{F}=0.5$ and $\mathrm{F}=0.75$ populations, respectively) and 2) a true reduction of flowering trees (6.7 and $13.1 \%$ more trees having no flowers for $\mathrm{F}=0.5$ and $\mathrm{F}=0.75$ populations than $\mathrm{F}=0$ population, respectively). Despite significant 
inbreeding depression on the percentage of female reproductive trees and the number of cones on adult trees, overall inbreeding depression on fecundity was low in radiata pine. One founder clone contributed most of the significant inbreeding depression observed for the population of eight founder clones. It was observed that fecundity varied more widely among the eight clones than among the inbreeding level (self and outcross).

Key words: Radiata pine, Pinus radiata, inbreeding depression, reproductive ability, fecundity, fitness.

\section{Introduction}

A major deterrent of adopting an inbreeding-hybrid breeding strategy in tree improvement program is the effect of inbreeding depression observed on reproductive traits in several conifer species (WILliams and SAVOLAINEN, 1996). Inbreeding depression on adult fecundity has three major implications in tree improvement. First, inbreeding depression in adult reproductive traits can result in the loss of valuable selections (clones) as they contribute little or nothing to subsequent generations. Second, the effects of the inbreeding depression on adult reproductive ability may retard recurrent breeding operations and prolong the completion of the breeding cycle in operational breeding programs. Third, the out-crossed embryos that later develop on an inbred maternal parent may exhibit reduced fitness as an indirect consequence of parental inbreeding depression. Therefore, more than one generation of outcrossing may be necessary to restore vigor. Such maternal effects of reduced seed potential and delayed onset of reproduction in inbred trees can also delay the production of superior hybrid seeds and make the production of hybrid seeds more expensive.

In conifers, inbred individuals have been observed to have a lower average fitness at all life stages (embryo development, seedling to adult growth, and reproductive abilities). However, reliable reports on adult reproduction in inbred conifers are very rare due to the long-term nature of such studies. In a few published reports inbreeding depression has been observed for onset of reproduction as well as the number and size of male and female strobili. Most reports of adult fecundity have, however, been limited to qualitative observations. In jack pine (Pinus banksiana), a precociously flowering species, there was a delay in age of first flowering and a reduction in strobilus number (RUDOLPH, 1976). A 3-year delay was observed for western white pine (Pinus monticola) as well as a 15 to $26 \%$ reduction in fitness after one generation of selfing (BINGHAM, 1973). Flowering age was not delayed for loblolly pine (Pinus taeda), but there was about a $30 \%$ decline in number of potential sites for seeds in female cones of selfed maternal parents (SNIEZKo, 1984). In Douglas-fir (Pseudotsuga menziesii), no flowering age data were reported, but male strobili and developing conelets were smaller on selfed individuals when compared to their outcrossed half-sibs (ORR-EwING, 1965). There is also substantial variation in the number of seeds and germination of seed from control-pollinated cones among three inbreeding levels (outcrossed, first- and second-generation selfs of two clones) (ORREwING, 1976). A very severe reduction in the number of cones in the first- and second-generation selfs has been observed (53 and $89 \%$ depression, respectively) in maritime pine (Pinus pinaster) (DUREL et al., 1996).

Two issues relating to inbreeding effects on reproductive ability in the long-lived trees should be examined. Whether 1) inbreeding only delays reproduction age or 2 ) if inbreeding simply reduces reproductive ability. If inbreeding only delays reproductive age, the effect of inbreeding depression on fecun- dity may be a byproduct of its effects on growth. This is because inbred trees grow slower than out-crossed progenies, on average. If inbreeding reduces adult flowering, it may be caused by recessive alleles for reproductive traits. All previous inbreeding studies in trees reported inbreeding effects only on reproductive ability at a very early (juvenile) age (age 1 to 4 years) except for maritime pine at age 11 years (DUREL et al., 1996). Therefore, reported results do not discriminate between the delay of reproduction age of inbred trees and reduced adult flowering. Distinguishing these two types of inbreeding depression on reproduction may shed light on the genetic causes of inbreeding depression on reproductive traits. Therefore, it is desirable that inbreeding depression on fecundity is examined for both types.

We have previously reported on a radiata pine (Pinus radiata) experiment involving five levels of inbreeding in which inbreeding reduced survival and growth, but increased variation of growth traits. Furthermore, the numbers of sound seeds and growth rate did not decline significantly from the firstgeneration of selfs $\left(\mathrm{S}_{1}\right)$ to the second-generation of selfs $\left(\mathrm{S}_{2}\right)$ (GRIFFIN and LiNDGREN, 1986; Wu et al., 1998a, 1998b, 2002; Matheson et al., 2002). A further logical question is whether inbreeding has severe adverse affects on the reproduction of radiata pine. In a previous preliminary study of radiata pine, selfing was observed to have little effect on adult flowering in the first-generation selfed progenies (PAWSEY, 1964). These findings suggest that selfing might be effective in purging deleterious alleles from populations of radiata pine and could be used to produce superior inbred lines and hybrids. In this report, we quantitatively investigate inbreeding effects on fecundity of young and adult trees up to two generations of selfs in radiata pine. The reproductive traits examined include the percentage of trees bearing female strobili and the number of female cones and flowers on each tree. We are particularly interested in answering the following questions: 1) whether inbreeding delayed the onset of reproduction, 2) whether inbreeding reduced adult fecundity, and 3) whether there are clonal effects of inbreeding depression on reproduction.

\section{Material and Methods}

\section{The experiment}

Two radiata pine inbreeding experiments were surveyed for their fecundity. The first radiata pine inbreeding experiment was set up in the1980s in Mount Gambier, South Australia, as a comprehensive study of the effect of inbreeding in radiata pine. The detailed mating design and field experiment were described by Wu et al. (1998a). With this mature experiment (18 year-old at the time of the final flowering survey), we investigated adult reproduction in three populations: 1) a noninbred base population, which is consisted of progenies from crosses among eight unrelated, non-inbred founder clones and is designated as $\mathrm{S}_{0}$ (population 1) with the inbreeding coefficient $\mathrm{F}$ equal to $0 ; 2$ ) a population of the first-generation selfs (population $4, \mathrm{~F}=0.5$, also called $\mathrm{S}_{1}$ ), created by selfing the eight founder clones; and 3) a population of the second-generation selfs (population $5, \mathrm{~F}=0.75$, also called $\mathrm{S}_{2}$ ), created by selfing the selected first-generation selfs at age 4 and 5 years from planting. Selfed progenies $\left(\mathrm{S}_{1}\right)$ from one founder clone (Clone 1 ) did not flower during the controlled pollination seasons (1976 and 1977) used in creating the second-generation selfs. Therefore, the $\mathrm{S}_{2}$ population consists only of 7 founder clones. These three populations were planted at Mount Gambier, South Australia at a site called Symons in 1981 with four replications and the two populations $\left(\mathrm{S}_{0}\right.$ and $\left.\mathrm{S}_{1}\right)$ were also planted at a second site nearby (about $1.2 \mathrm{~km}$ from the first site) called Kilsbys 
in 1982 with six replications. A six-tree row plot was used and spacing was $2 \mathrm{~m} \times 3 \mathrm{~m}$ at both sites.

In 1993, a systematic thinning was conducted to remove the second and third trees in each six tree row plots. The fecundity survey was first conducted in the 1997 flowering season (July and August) at age 15 and 16 years from planting for the two sites, respectively. The number of female flowers on each tree of the two selfed populations $\left(\mathrm{S}_{1}\right.$ and $\left.\mathrm{S}_{2}\right)$ was recorded. It was observed that some trees which did not flower in 1997 had cones with viable seeds from previous years, while some trees which did flower in 1997 had no mature cones (no accumulated cones). It was decided that both old cones and recent-year flowers should be counted simultaneously to truly reflect the fecundity of selfed trees. In 1999 (age 17 and 18 years from planting), the total number of cones on each tree as well as the number of new flowers was recorded. Due to the size of the trees (most trees were between 12 and $24 \mathrm{~m}$ tall), an elevated platform vehicle (reaching $25 \mathrm{~m}$ in height) was used to examine all branches and trunks for flowers and accumulated cones. Sixteen trees were too high (over $28 \mathrm{~m}$ ) for counting female flowers and these trees were more or less even distributed among the three inbreeding levels. Therefore the number of female flowers for these 16 trees were counted as missing. Hence, comparisons between inbred and outcrossed progenies of the same pedigree are possible. Reproductive ability for male flowers (strobili) was not investigated because it is extremely difficult to quantify the male strobili because of the large size of the trees. In addition, almost all trees produced pollen, although a large variation between clones was observed.

Two families in population $\mathrm{S}_{0}$ (out-crossed) and four families in population $\mathrm{S}_{1}$ were planted only at the Kilsbys site. It was desirable to include these families into the analysis of main Symons trial. Six families in population $\mathrm{S}_{0}$ and four families in population $\mathrm{S}_{1}$ were planted at both sites. For these common families, a linear model was fitted to investigate family by site and family by replicate interactions for the two populations separately. It was found that the interaction between families and sites was not significant for either population and thus data across sites could be combined. Data from Kilsbys were adjusted and combined with data from Symons using the method described in Wu et al. (1998a).

The second inbreeding experiment was set up in 1997 to investigate the inbreeding effect on the onset age of reproduction. Five populations with inbred level from $\mathrm{F}=0$ to $\mathrm{F}=0.75$ (e.g. population 1 with $\mathrm{F}=0$, population 2 with $\mathrm{F}=0.125$, population 3 with $\mathrm{F}=0.25$, population 4 with $\mathrm{F}=0.50$, and population 5 with $\mathrm{F}=0.75$ ) were planted at two sites using stored seeds of remaining families (65 families) from the first experiment (136 families in total). All four inbred populations in the new 1997 trials come from the same populations as in the first experiment. However, the out-crossed population $\left(\mathrm{S}_{0}, \mathrm{~F}=0\right)$ in this new trial is derived from crosses between unrelated selfed progenies (the first-generation). Both female and male flowers were surveyed from year 2000 (age 3 years) to 2002 (age 5 years) at one site.

\section{Statistical analysis.}

For the first and mature experiment, the trees, which have either female flowers or cones or both, are regarded as female reproductive trees and the percentage of reproductive trees was calculated for each family. Raw data were also separated according to each founder clone. A preliminary analysis revealed that there was no interaction between replication and inbreeding level, and so, all three female reproductive traits; \% reproductive (fecund) trees, number of cones per tree, and number of female flower per tree were subjected to the following analysis of variance:

$$
Y_{i j k l}=\mu+R_{i}+P_{j}+C_{k}+P C_{j k}+E_{i j k l}
$$

where $\mu$ is grand mean, $R_{i}$ is the ith replicate effect, $P_{j}$ is the $\mathrm{jth}$ population (inbreeding level) effect, $\mathrm{C}_{\mathrm{k}}$ is the kth founder clone effect, $\mathrm{PC}_{\mathrm{jk}}$ is the interaction between jth inbreeding level and kth founder clones, and $\mathrm{E}_{\mathrm{ijkl}}$ is the residual. All effects were assumed fixed except for residual. SAS GLM type III estimable functions (SAS Institute Inc. 1989) were used to estimate mean squares and hypothesis testing.

To estimate inbreeding depression for the whole population and individual founder clones, a linear regression was fitted for whole population and individual founder clones:

$$
Y=\alpha+\beta(\mathrm{F})+E
$$

where $\mathrm{Y}$ represents the phenotypic value, $\alpha$ the intercept (estimated population mean when $F=0$ ), $\beta$ the regression line or slope, $F$ the inbreeding coefficient, and $\mathrm{E}$ the residual error term.

For the second experiment, analysis was done at the population level only. This is because data are not as balanced as in the first experiment (e.g. not all populations have progenies of all eight founder clones). Therefore, ANOVA was done according to model:

$$
Y_{i j l}=\mu+R_{i}+P_{j}+R P_{i j}+E_{i j l}
$$

We were mainly focusing on female fecundity in this study. The term female fecundity refers to the numbers of female flowers (or cones) in a tree.

Table 1. - Analysis of variance for percentage of reproductive trees (after arcsine square root transformation), cumulative cone number, and female flower number in 1999 (after square root transformation) in an 18 years-old radiata pine inbreeding experiment.

\begin{tabular}{|l|l|l|l|l|l|l|l|l|l|}
\hline & \multicolumn{3}{|l|}{$\begin{array}{l}\text { Percentage of } \\
\text { reproductive trees }\end{array}$} & \multicolumn{3}{l|}{ Cone number } & \multicolumn{3}{l|}{ Flower number } \\
\hline $\begin{array}{l}\text { Sources of } \\
\text { variation }\end{array}$ & DF & MS & Pr $>$ F & DF & MS & Pr $>$ F & DF & MS & Pr $>$ F \\
\hline Replication & & & & 5 & 5.58 & $0.001^{* *}$ & 5 & 2.07 & 0.100 \\
\hline Inbreeding level & 2 & 0.288 & $0.022^{*}$ & 2 & 23.39 & $0.033^{*}$ & 2 & 1.40 & 0.282 \\
\hline Founder clones & 7 & 0.136 & 0.088 & 7 & 11.35 & $0.001^{* *}$ & 7 & 6.40 & $0.001^{* *}$ \\
\hline Interaction & 13 & 0.051 & 0.742 & 13 & 1.59 & 0.076 & 13 & 1.17 & 0.393 \\
\hline Residual & 56 & 0.071 & & 778 & 0.99 & & 770 & 1.10 & \\
\hline
\end{tabular}

a There is no replication effects for percent of reproductive tree since percentage was calculated by pooled data across replications.

$* \mathrm{P}<0.05 \%$, ** $\mathrm{P}<0.01 \%$ 


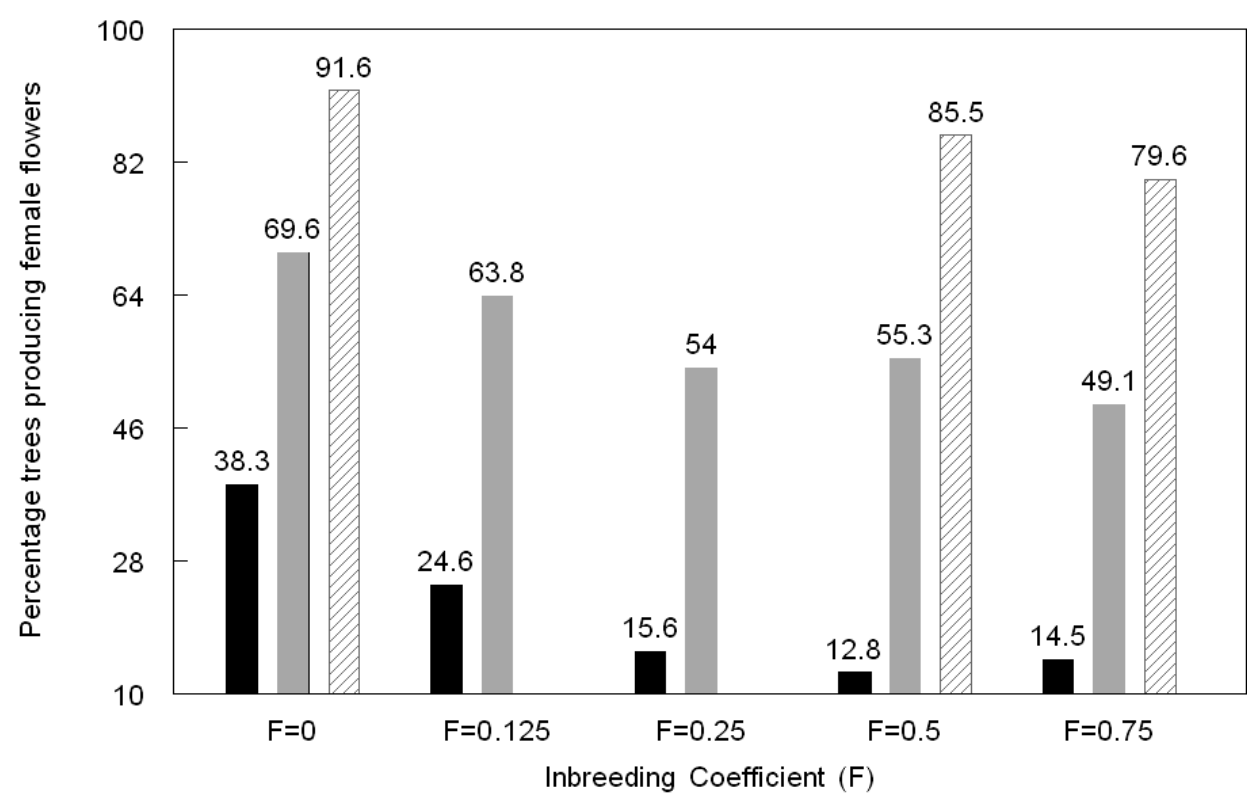

Figure 1. - Inbreeding effect on female fecundity at three different ages in radiata pine.

\section{Results}

\section{Inbreeding effect on fecundity of young and adult trees}

Inbreeding (sib-mating and selfing) significantly reduced the percentage of trees that reproduce (cones and female flowers, Table 1 and Figure 1). It was observed that the percentage of adult trees that produce female flowers decreased from $91.6 \%$ for out-crossed progenies $(\mathrm{F}=0)$ to $85.5 \%$ after the first-generation of selfing and to $79.6 \%$ after the second-generation of selfing (Figure 1). This translated to a $6.1 \%$ decrease in the percentage of adult female flowering trees in the out-crossed population compared to the first-generation selfs and a further 5.9\% decrease from the first-generation selfs compared to the second-generation selfs. Inbreeding had more of an effect on younger trees than mature trees for female reproduction. For example, population $2(\mathrm{~F}=0.125), 3(\mathrm{~F}=0.25), 4(\mathrm{~F}=0.50)$ and 5 $(\mathrm{F}=0.75)$ had reduced fecundity of $8,22,21$, and $29 \%$ respectively at age five years-old (Figure 1).
Analysis based on individual founder clones revealed that only one clone (Clone 2) had a significant decrease in the percentage of female trees that had flowers or cones after selfing (Table 2, Figure 2). Inbreeding up to two generations of selfing had no significant effects on the percentage of adult flowering trees and number of cones for the other seven clones. For clone 2 , the reduction in percentage of adult flowering trees was $13.5 \%$ from out-crossed progenies compared to the first-generation selfs and a further $7.5 \%$ decrease from the first-generation selfs compared to the second-generation selfs.

Differences between the founder clones were observed for the percentage of adult flowering trees at the $8.8 \%$ probability level. The average percentage of trees that reproduce across the three inbreeding levels $\left(\mathrm{S}_{0}, \mathrm{~S}_{1}\right.$, and $\left.\mathrm{S}_{2}\right)$ varied from $80 \%$ for clone 2 to $97.3 \%$ for clone 4 . There were only two inbreeding levels (the out-crossed and the first-generation selfs) for clone 1 and it had the lowest cone number per tree in the first-genera-

Table 2. - Linear regression of percentage of reproductive trees (after arcsine square root transformation), cumulative female cone number and female flower number (after square root transformation) in 1999 in an 18 year-old radiata pine, based on population and individual founder clones.

\begin{tabular}{|l|l|l|l|l|l|l|}
\hline & \multicolumn{2}{|l|}{$\begin{array}{l}\text { Percentage reproductive } \\
\text { trees }\end{array}$} & \multicolumn{2}{l|}{ Female cone number } & \multicolumn{2}{l|}{ Flower number } \\
\hline & \multicolumn{1}{|c|}{$\alpha$} & \multicolumn{1}{l|}{$\beta$} & $\alpha$ & \multicolumn{1}{l|}{$\beta$} & $\alpha$ & $\beta$ \\
\hline Population & $1.346^{* *}$ & $-0.210^{*}$ & $1.903^{* *}$ & $-0.307^{*}$ & $1.104^{* *}$ & -0.132 \\
\hline Clone 1 & $1.318^{* *}$ & -0.653 & $1.557^{* *}$ & -0.747 & $0.696^{* *}$ & -0.354 \\
\hline Clone 2 & $1.266^{* *}$ & $-0.364^{* *}$ & $1.781^{* *}$ & $-0.664^{*}$ & $1.197^{* *}$ & -0.926 \\
\hline Clone 3 & $1.396^{* *}$ & -0.322 & $2.100^{* *}$ & 0.125 & $1.306^{* *}$ & -0.548 \\
\hline Clone 4 & $1.392^{* *}$ & 0.248 & $2.373^{* *}$ & -0.198 & $1.341^{* *}$ & 0.241 \\
\hline Clone 5 & $1.399^{* *}$ & -0.606 & $1.641^{* *}$ & -0.292 & $1.059^{* *}$ & -0.026 \\
\hline Clone 6 & $1.267^{* *}$ & -0.165 & $1.590^{* *}$ & -0.413 & $1.099^{* *}$ & -0.397 \\
\hline Clone 7 & $1.285^{* *}$ & -0.360 & $1.852^{* *}$ & -0.122 & $0.810^{* *}$ & 0.381 \\
\hline Clone 8 & $1.458^{* *}$ & -0.164 & $2.482^{* *}$ & -0.449 & $1.537^{* *}$ & 0.094 \\
\hline
\end{tabular}

$\alpha$-intercept, $\beta$ - coefficient of regression, $\mathrm{n}$ - indicates non-significant, $* * \operatorname{Pr}<0.01$ and $* \operatorname{Pr}<0.05$. 


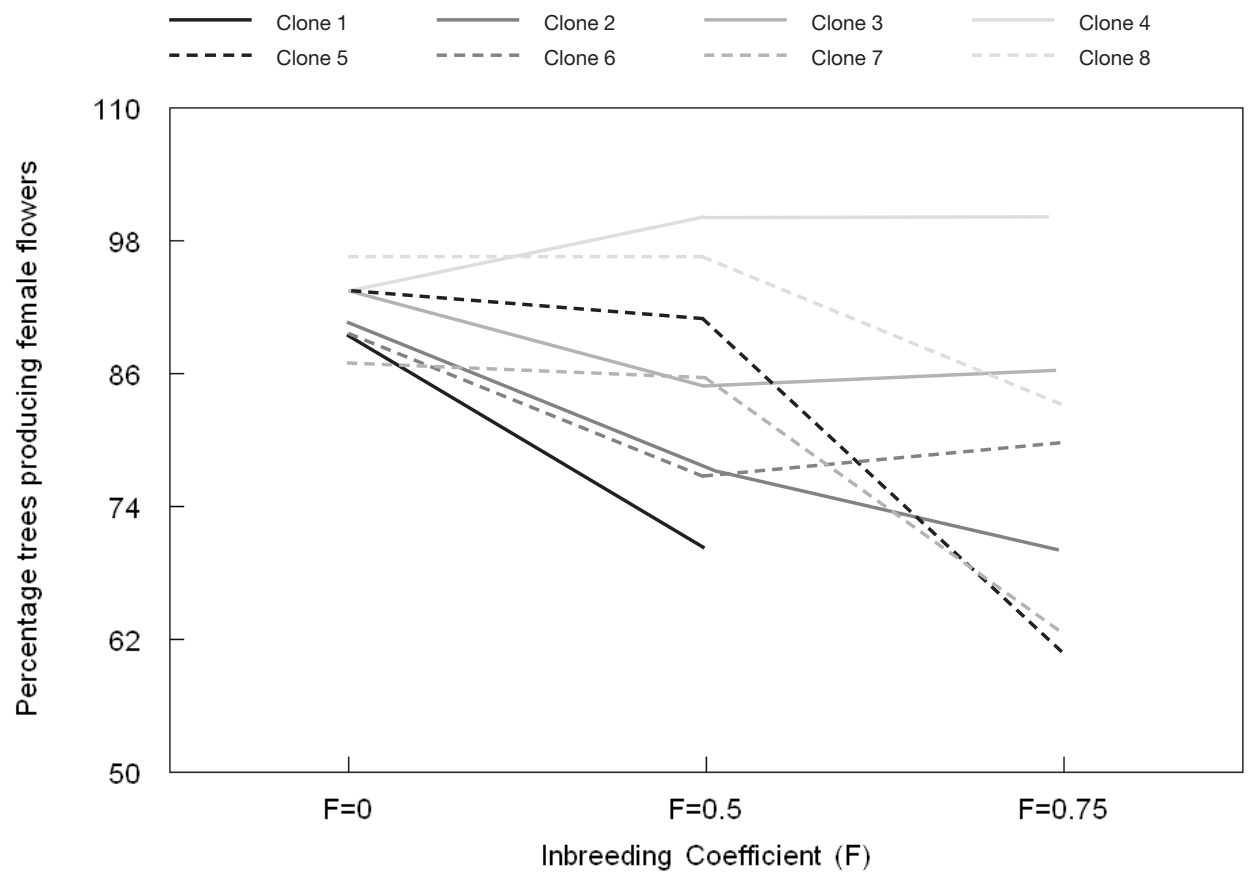

Figure 2. - Inbreeding effect on female fecundity on eight founder clones in a 18 year old radiata pine trial.

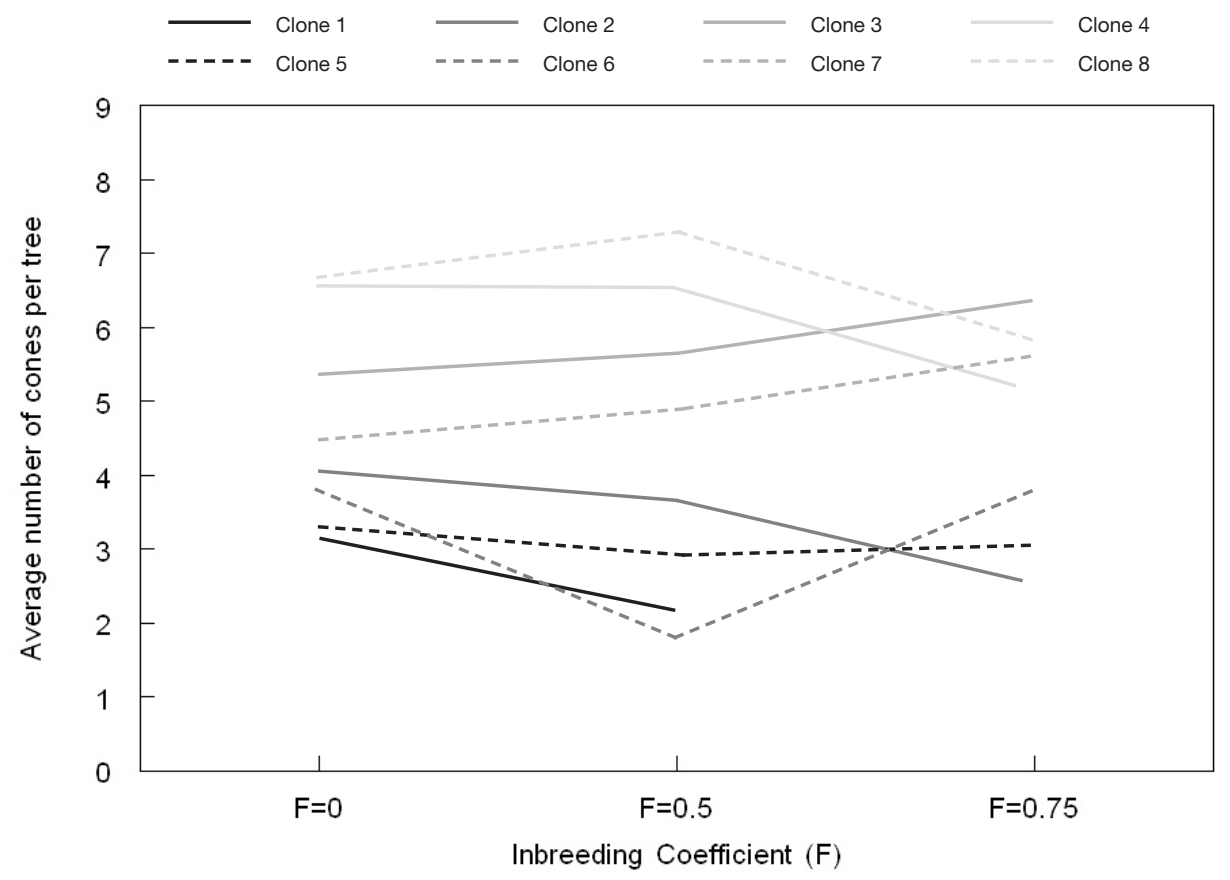

Figure 3. - Inbreeding effect on cone production among eight founder clones in a 18 year old radiata pine trial.

tion selfs. We note that this clone was not used to produce $\mathrm{S}_{2}$ progeny in the 1976-1977 pollinations because it had no female flowers.

The average cone number on adult trees varied from 4.6 cones per tree for the out-crossed population $(\mathrm{F}=0)$ to 4.3 cones per tree for the second-generation inbred trees $(\mathrm{F}=0.75)$, but statistically, the difference is significant at the $3.3 \%$ probability level (Table 1). Similarly, there were significant, but large differences between clones in the number of cones per adult tree (Figure 3). Clone 1 had the lowest cone number, at 2.9 cones per tree on average, and Clone 4 and 8 had the highest number of cones per tree, at 6.1 and 6.8 cones per trees, on average respectively. Significant differences between replications were also observed in the cumulative cone number, but the interaction between inbreeding level and founder clone was not statistically significant (Table 1).

Similar to the percentage of reproductive trees, regressions of cone number on inbreeding level for whole populations and 


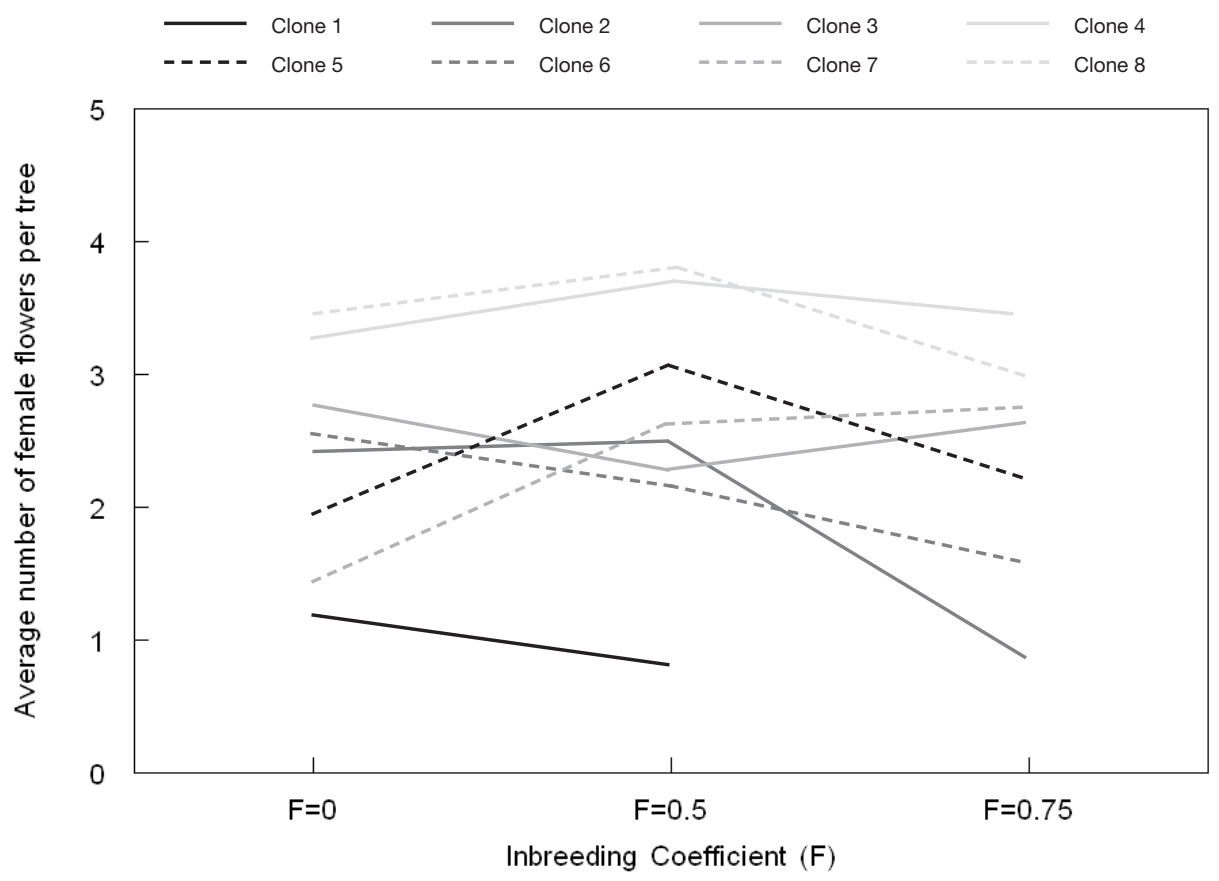

Figure 4. - Inbreeding effect on female flower production among eight founder clones in a 18 year old radiata pine trial.

for clone 2 individually were significant while regressions for all other clones individually were not significant. For clone 2, the average number of cones per tree among outcrosses was reduced by 0.4 compared to the first-generation of selfs and a further 1.1 cones per tree from the first-generation selfs compared to the second-generation selfs. Clone 6 had a considerable decrease in cone number from the out-crossed population to the first-generation selfs (3.8 to 1.9 cones/tree) and then a sizable increase (1.9 to 3.9 cones/tree) from the first-generation selfs to second-generation selfs. We also observed that clone 1 , along with clone 6 had the lowest cone number in the first-generation selfs (Figure 3).

The number of female flowers on adult trees varied from 2.3 flowers per tree for the out-crossed population compared to 2.6 and 2.2 for the first- and the second-generation selfs respectively. However, the differences were not statistically significant. In contrast, the founder clone had a highly significant

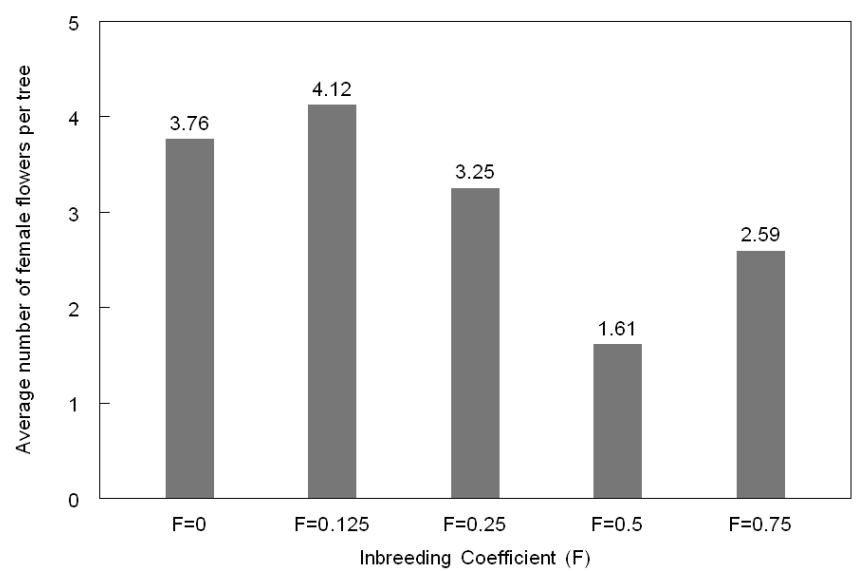

Figure 5. - Inbreeding effect on female flower production in a five year old radiata pine trial. effect on the number of female flowers (Table 1, Figure 4). The number of female flowers varied from 1.1 flowers per tree in Clone 1 to 3.4 and 3.5 per tree in Clones 4 and 8 , respectively (Figure 4). No individual clone was observed to have a significant relationship between inbreeding levels and female flower number. However, it was observed that both Clones 4 and 8 had the highest number of cone and female flowers while Clone 1 had the lowest number of cone and female flowers on adult trees.

While there were no significant differences in female flower production between the three inbred levels $(\mathrm{F}=0, \mathrm{~F}=0.5$, and $\mathrm{F}=0.75$ ) on adult trees, there were significant differences between all five inbred levels in young trees (Figure 5). Trees at age five years produced 3.8, 4.1, 3.3, 1.6, 2.6 flowers per tree for inbreeding level of $\mathrm{F}=0, \mathrm{~F}=0.125, \mathrm{~F}=0.25, \mathrm{~F}=0.5$, and $\mathrm{F}=0.75$, respectively. This translated into an inbreeding depression of $-9.6,13.6,57.2$, and $31.1 \%$ for the four inbred levels $(\mathrm{F}=0.125, \mathrm{~F}=0.25, \mathrm{~F}=0.5$, and $\mathrm{F}=0.75)$, respectively.

\section{Inbreeding effect on onset age of reproduction}

There were no female flowers observed on trees in the new trial for the first two years after planting. At year three, one tree $(2.1 \%$ of the total of 47 trees) from the population 1 had female flowers while $1.6 \%$ ( 5 trees from a total of 307 ), $2.6 \%$ ( 8 trees from a total of 309), $0.0 \%$ (total 40 trees), and $6.3 \%$ (8 trees from a total of 128) trees from the populations $2,3,4$, and 5 , respectively, produced female flowers. More trees in all five populations produced female flowers at age four years. For example, populations $1,2,3,4$, and 5 , respectively had 38.3 , $24.6,15.6,12.8$, and $14.5 \%$ of trees producing female flowers in years three and four. The difference on female fecundity was statistically significant from age four years onward. Again more trees start to reproduce at age five with $69.6,63.8,54.0$, 55.3 , and $49.1 \%$ of trees, respectively for population $1,2,3,4$, and 5 showing female flowering. From a comparison of female fecundity data between age four and five years, inbreeding seems to delay onset of reproduction for $7.9,7.1,11.2$, and $3.3 \%$ 


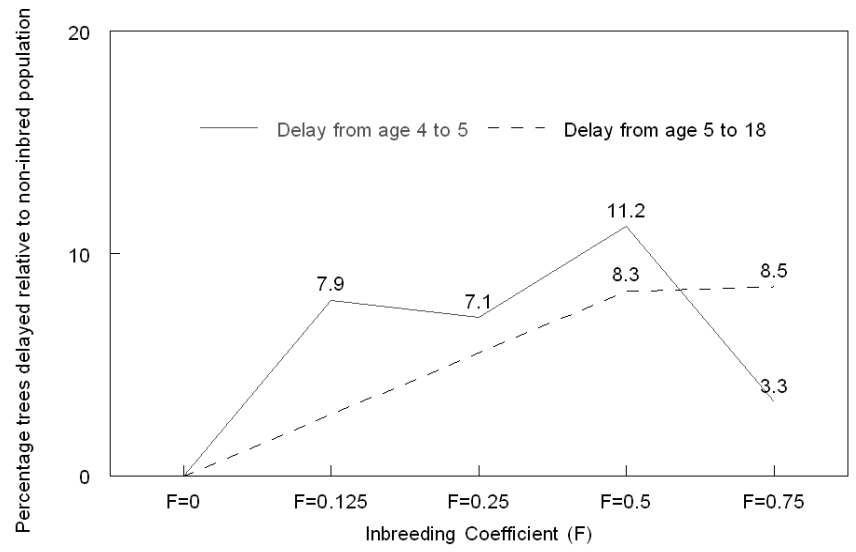

Figure 6. - Inbreeding effect on percentage tree that was delayed for female reproduction in radiata pine based on two time intervals.

trees, respectively for population $2,3,4\left(\mathrm{~S}_{1}\right)$, and $5\left(\mathrm{~S}_{2}\right)$ relative to the non-inbred population $1\left(\mathrm{~S}_{0}\right)$ from age four to age five years (Figure 6). A comparison between age five female fecundity data and data from mature trees in the first experiment for the three populations $\left(\mathrm{S}_{0}, \mathrm{~S}_{1}\right.$, and $\left.\mathrm{S}_{2}\right)$ suggests that inbreeding has delayed onset of reproduction by 8.3, and 8.5\% trees for $\mathrm{S}_{1}$ and $S_{2}$ populations, respectively, relative to the non-inbred population from age five to 18 years ((Figure 6).

\section{Discussion and Conclusion}

Inbreeding depression has been studied in many species of conifers. Severe depression has been usually observed for reproductive traits in young trees. With young trees, it is impossible to distinguish inbreeding depression on fecundity due to delay on onset of flower production or due to a true reduction of trees producing flowers. In this study, we examined reproductive ability in both young and adult trees of the same pedigrees (although the population at young age is smaller). With such a comparison, we are able to examine the causes of early inbreeding depression on fecundity (delay of reproduction phase or a reduction of fecund trees). We observed that selfing delayed production of female flowers in about $8 \%$ of the trees. We also observed that selfing delayed female reproduction in founder Clone 1 . This is because $\mathrm{S}_{1}$ progenies of Clone 1 had not produced female flowers at age 4 and 5 . However, at age $18, \mathrm{~S}_{1}$ progenies from the Clone 1 did produce female flowers and cones although their reproductive ability was less than other founder clones.

The observations of inbreeding effects on reproduction of young and adult trees in radiata pine from this study can be summarized as:

1. Inbreeding depression on female flowering at young ages up to age 5) was higher than in mature trees (21 and $29 \%$ at age five relative to 6.7 and $13.1 \%$ at age 8 for $\mathrm{F}=0.5$ and $\mathrm{F}=0.75$ populations).

2. Inbreeding depression on female flowering at young ages was caused by a delay in the onset of reproduction as well as a decrease in number of trees that can reproduce. About $8 \%$ trees had delayed female flowering in the $\mathrm{F}=0.5$, and $\mathrm{F}=0.75$ populations, respectively.

3. Inbreeding also decreased the average numbers of female flowers on young trees and average cone production on adult trees while there was no significant inbreeding depression in female flower number on adult trees. Inbreeding depression on number of cones per adult tree was only $5.7 \%$ from $\mathrm{F}=0$ to $\mathrm{F}=0.5$ and only $6.5 \%$ from $\mathrm{F}=0$ to $\mathrm{F}=0.75$.
4. Inbreeding depression on the percentage of flowering tree and the cone number of adult tree was mainly due to one founder clone among the eight founder clones studied.

5 . The effect of founder clone was larger than that of inbreeding level on adult reproductive traits (number of cones and female flowers).

6. In this particular study, it was found that founder Clones 4 and 8 had the highest and Clone 1 had the lowest adult fecundity.

These observations on flower incidence are consistent with an early qualitative study by PAWSEY (1964). Based on 40 inbred progenies, ranging from age four to 12 years, Pawsey observed that the $S_{1}$ progenies contained from 0 to $10 \%$ of trees bearing flowers at age three from planting, on a medium site, while about $1 \%$ of the routine planting stock did so in the same area. At four years of age, the corresponding percentages ranged as high as $15 \%$ for the $\mathrm{S}_{1}$ progenies, while the routine stock was about $12 \%$. In addition, the proportion of cones reaching maturity was observed at 55,56 and $60 \%$ for the outcrossed, the first-, and the second-generation selfs. Based on these observation, it was concluded that inbreeding in radiata pine had not adversely affected flowering, nor, in general, the proportion of cones reaching maturity, in contrast to the present study.

The weak inbreeding depression in radiata pine reproductive traits observed in this study is also consistent with relative weak inbreeding depression on the growth vigor traits (WU et al., 1998). In comparison with other conifers, radiata pine seems to be less sensitive to inbreeding for both growth and reproductive traits. Radiata pine had the lowest inbreeding depression in growth (DBH and height) (WILCOX, 1983; Wu et al., 1998) and also the lowest inbreeding depression on adult fecundity. For example, very severe depression on number of cones in the first-generation and second-generation progenies of selfs was observed (53 and 89\% depression, respectively) in maritime pine at age 11 years (DUREL et al., 1996), but the maturation phase was suspected not to be fully achieved for many inbred trees. In western white pine, a 15 and $26 \%$ reduction in female and male flower production were observed in the first-generation selfs (BINGHAM, 1973).

The low inbreeding depression seems to confirm our earlier suggestion that significant genetic load has been removed in radiata pine throughout the evolutionary history or through early purging in seed production, nursery culling and mortality. This lower genetic load, lower than any other conifer, can be explained by purging in natural radiata pine populations in California, due to its remnant small population (MORAN and BELL, 1987), and strong geographic isolation (ELDRIDGE, 1998).

One noticeable observation in this study is the relatively large variation between clones on fecundity. In fact, variation in adult fecundity between the eight founder clones was larger than the effect of inbreeding levels. This may indicate other reproductive studies involving different clones at different inbreeding levels may confound inbreeding effects with clone effects.

The higher mortality in $\mathrm{S}_{1}$ and $\mathrm{S}_{2}$ relative to $\mathrm{S}_{0}$ population might have reduced estimates of inbreeding depression on adult reproductive ability. This is because more trees in $\mathrm{S}_{1}$ and $\mathrm{S}_{2}$ populations died at age 18 year. It was observed that at age 13 year, 7 and $11 \%$ more trees died in $S_{1}$ and $S_{2}$ relative to $S_{0}$, and at age 18 year, 10 and $16 \%$ more trees died in $S_{1}$ and $S_{2}$ relative to $S_{0}$. Most trees that died were small, suppressed, and unlikely to be able to reproduce. Whether this was due to suppression or other genetic causes is not known. The differential 
competition levels in $\mathrm{S}_{0}, \mathrm{~S}_{1}$ and $\mathrm{S}_{2}$ populations may also affect estimates of inbreeding depression. This is because, there is more competition in $\mathrm{S}_{0}$ population relative to $\mathrm{S}_{1}$ and $\mathrm{S}_{2}$, due to a higher survival rate in the $S_{0}$ population. More severe competition in $S_{0}$ population may reduce the exposure of trees to light, and correspondingly, may reduce the number of flowers. Therefore differential competition levels in the adult inbreeding trial may decrease estimates of inbreeding depression.

For tree breeders to adopt the inbreeding/crossbreeding approach as an appropriate novel breeding strategy for conifers, four potential questions must be addressed:

1. It must be feasible to derive superior inbred lines (trees) from selfing.

2. There must be heterosis in crosses between these inbred lines.

3. Inbreeding should not substantially delay reproductive age or reproductive ability.

4. Early selection among inbreds must be effective in order to select superior inbred lines as quickly as possible.

We have observed that inbreeding depression in growth vigour ( $\mathrm{DBH}$, height) is the lowest in radiata pine relative to other conifers and that it is possible to obtain superior inbred trees (lines) from selfing (Wu et al., 1998a). It was also observed that there is more segregation in the $\mathrm{S}_{1}$ and $\mathrm{S}_{2}$ than in the sib-mated inbred and the out-crossed populations, and that the largest trees in the trial (including the out-crossed population) were among the $\mathrm{S}_{2}$. In addition, it was observed that early selection among inbred lines is more effective than out-crossed population (MATHESON et al., 2002). In this and previous (PAWSEY, 1964) studies, it has been observed that inbreeding depression of fecundity in radiata pine was not severe. Based on these observations, it seems that inbreeding/ crossbreeding approach would be an attractive alternative breeding strategy in radiata pine breeding program.

\section{Acknowledgements}

Dr. ROD GRIFFIN initially conceived the inbreeding experiment, and R. F. HAND carried out crosses for this inbreeding experiment. Field planti- ngs were organised by K. W. JoHNSON. We are grateful to CSR Timber Products Ltd (now Green Triangle Timber Products Ltd) for the use of the two sites (Symons and Kilsbys) at Caroline Forest near Mt Gambier and Hancock Victoria Plantations Ltd for use of one site at Tyers. DAVID SPENCER organized establishment of 1997 field trials.

\section{Literature cited}

BIngham, E. T.: Possibilities for improvement of western white pine by inbreeding. USDA For. Ser. Res. Pap. INT-44, 18 p. 1973. — DUREL, C. E., Bertin, P., and Kremer, A.: Relationship between inbreeding depression and inbreeding coefficient in maritime pine (Pinus pinaster). Theor. Appl. Genet. 92: 347-356 (1996). - GRIFFIN, A. R. and LindGREN, D. Effect of inbreeding on production of filled seed in Pinus radiata - experimental results and a model of gene action. Theor. Appl. Genet. 71: 334-343 (1985). - Matheson, A. C., Wu, H. X. Spencer, D. J., RaYMOND, C. A. and GRIFFIN, A. R.: Inbreeding in Pinus radiata: III. The effect of inbreeding on age-age correlation and early selection efficiency. Silvae Genet. 51: 115-122 (2002). - Moran, G. F. and BELL, J. C.: The origin and genetic diversity of Pinus radiata in Australia. Theor. Appl. Genet. 73: 616-622 (1987). - MorAN, G. F., BELl, J. C. and EldRIDGE, K. G.: The genetic structure and the conservation of five natural populations of Pinus radiata. Can. J. For. Res. 18: 506-514 (1988). - ORREwING, A. L.: Inbreeding and single crossing in Douglas-fir. For. Sci. 11: 279-290 (1965). - ORR-EwING, A. L.: Inbreeding Douglas-fir to the S3 generation. Silvae Genet. 25: 179-183 (1976). — PAWSEY, C. K.: Inbreeding radiata pine. Dept Nat. Dev. For. and Timb. Bur. Leaflet No 87, Forest Research Institute, Canberra 31 pp. (1964). - RUDOLPH, T. D. Cone set, seed yield. Seed quality, and early seedling development of S2 generation jack pine. Proceedings of the Tenth Central States Forest Tree Improvement Conference, Purdue University. West Lafayette. Pp 42-60 (1976). - SAS Institute Inc.: SAS/STAT User's Guide, Version 6, $4^{\text {th }}$ Edition, Volume 1\&2, Cary, North Carolina (1989). - SNiEzko, R. A.: Inbreeding and outcrossing in loblolly pine. Unpublished Ph.D. Thesis. North Carolina State Univ., Raleigh, North Carolina. 50 p. (1984) - Wilcox, M. D.: Inbreeding depression and genetic variances estimated from self-and cross-pollinated families of Pinus radiata. Silvae Genet. 32: 89-96 (1983). - Williams, C. G. and Salvolainen, O.: Inbreeding depression in conifers: implications for breeding strategy. For. Sci. 42: 102-117 (1996). - Wu, H. X., Matheson, A. C. and Spencer, D. Inbreeding in Pinus radiata $\mathrm{I}$. The effect of inbreeding on growth, survival and variance. Theor. and Appl. Genet. 97: 1256-1268 (1998a). Wu, H. X., Matheson, A. C. and Spencer, D.: Inbreeding in Pinus radiata II. Time trend of inbreeding depression with tree age and effects on growth curve. N. Z. J. For. Sci. 28: 123-139 (1998b). - WU, H. X., Matheson, A. C. and ABARQUez, A.: Inbreeding in Pinus radiata IV. The effect of inbreeding on wood density. Ann. For. Sci. 59: 557-562 (2002). 


\section{Buchbesprechungen}

Erlebnis Hardtwald. Der Traum in Grün. Von PAtricia Blum (Hrsg.). 2004. G. Braun Buchverlag, Karlsruhe und Leinfelden-Echterdingen. ISBN 3-7650-8272-4. 144 Seiten mit 135 Abbildungen und 5 Karten. Gebunden 19,80 EUR (D) / 34,90 SFr.

Der Hardtwald erstreckt sich in der Rheinebene zwischen Rastatt und Graben-Neudorf bei Bruchsal. Als höfisches Jagdgebiet konzipiert, wurden noch vor der Stadtgründung von Karlsruhe für sternförmig ausgerichtete Wege Schneisen in den Wald gelegt. Diese Achsen prägen bis heute das Bild der Stadt und des Hardtwaldes. 24 fachkundige Autoren - u. a. von dem Forschungszentrum Karlsruhe, der Universität Karlsruhe, dem Naturkundemuseum in Karlsruhe, der Berufsakademie Karlsruhe, dem Forstamt und der Bezirksstelle für Naturschutz und Landschaftspflege - beschreiben den Hardtwald von unterschiedlichen Seiten.

Kultur und Geschichte: Der Leser wird in die Geschichte und gegenwärtige Entwicklung des Hardtwaldes eingeführt. Flurnamen sowie historische Stätten werden erläutert und die Rasse des vielseitigen Hardtpferdes vorgestellt. Natur: Binnendünen und Flugsandfelder prägen den Karlsruher Hardt, der neben der Hockenheimer Hardt einzigartig in Baden-Württemberg ist. Sie sind Zeugen der Erdgeschichte und wertvolle Lebensräume für eine eigene Pflanzen- und Tierwelt, die dem Leser an mehreren Beispielen (z. B. Kiefernmistel, Großer Eichenbock, Ziegenmelker, Gottesanbeterin) nahe gebracht wird. Der Leser erfährt auch einiges über Trinkwassergewinnung und die besondere Funktion des Waldes, die er hierbei als Filter einnimmt. Wissenschaft und Forschung: In dem dreiteiligen Abschnitt werden die Körpersprache der Bäume, die Bedeutung des Waldes für das Klima und die Geologie vorgestellt. Kunst und Holz: Bizarre Baumformen regen seit jeher die menschliche Phantasie an. Anhand der Majolika-Manufaktur sowie diverser Kunsthandwerke wird dargestellt, wie im Hardtwald Natur und Kunst vernetzt sind. Verwertung: Der Wald - nach dem Grundsatz der Nachhaltigkeit bewirtschaftet - steht als Quelle des nachwachsenden Rohstoffs Holz in diesem Abschnitt im Vordergrund. Dabei wird besonders auf wertvolle Furniere eingegangen. Licht, Nebel und Schatten verleihen dem Wald etwas Mystisches, daher fehlen Kapitel zu Sagen und Geschichten sowie Mystisches und Magisches nicht. Besonders hervorgehoben werden die Zusammenhänge geometrisch-geomantischer Strukturen im Raum Karlsruhe. Freizeit und Freizeittipps: Als Naherholungsgebiet für Karlsruhe und seine Umgebung ist der Hardtwald von unschätzbarem Wert. Tourenvorschläge für Wanderer, Radfahrer und Inlineskater laden zur Erkundung des Hardtwaldes in unterschiedlichem Tempo ein. Die Hardt und mehr: Im letzten Abschnitt wird dem Leser verständlich dargestellte Statistik, u. a. zur Entwicklung der Baumartenteile, geboten, und bei einem Blick über den Tellerrand werden noch die Namensvettern des Hardtwaldes erwähnt. Kulinarisches ist wiederholt in den Text eingesprengt, z.B. Wildrezepte, die einem das Wasser im Munde zusammenlaufen lassen.

Die Herausgeberin hat mit diesem Band „eine Heimatkunde der besonderen ART" vorgelegt. Fachlich präzise, verständlich geschrieben und mit zahlreichen Farbbildern illustriert, ist der Band eine gelungene Biographie, die einlädt, sich vom Zauber dieses Stückchens Natur einfangen zu lassen.

Title: "Experience Hardtwald. A dream in green".

M. LIESEBACH (Wien)
Biologische Invasionen: Neophyten und Neozoen in Mitteleuropa. Von I. KowARIK. 2003. Verlag E. Ulmer, Stuttgart. ISBN 3-8001-3924-3. 380 Seiten mit 73 Abbildungen und 76 Tabellen. Gebunden 69,90 EUR(D)/71,90 EUR(A)/116,-- SFr.

Änderungen des Verbreitungsgebietes von Pflanzen und Tieren gehören zu den natürlichen Prozessen der Evolution. Als biologische Invasionen definiert der Autor, der Ökosystemkunde und Pflanzenökologie an der TU Berlin lehrt, die durch menschliche Aktivitäten ermöglichte Ausbreitung von Pflanzen, Tieren und Mikroorganismen in Gebiete, die sie natürlicherweise zuvor nicht erreicht haben. Die vom Menschen ausgelösten Invasionen übertreffen das Ausmaß, die Reichweite, die Geschwindigkeit und die Auswirkungen natürlicher Arealerweiterungen von Arten. Daher haben biologische Invasionen weitreichende ökologische und evolutionäre, aber auch ökonomische und soziale Konsequenzen und gelten weltweit als wesentlicher Gefährdungsfaktor für die Biodiversität.

Das vorliegende Buch behandelt die eingeschleppten oder bewusst eingeführten Pflanzen- und Tierarten in mitteleuropäische Lebensräume. Nach Begriffserklärungen führt der Autor in biologische Invasionen weltweit ein. In den folgenden Kapiteln wird der Einfluss des Menschen auf diese Phänomene dargestellt. Es folgt eine umfassende Übersicht über Neophyten mit aktuellem Kenntnisstand zur Herkunft und Einführung der jeweiligen Arten, ihren aktuellen Vorkommen, ihren Erfolgsmerkmalen sowie den von ihnen verursachten Problemen. Neben zahlreichen Arten, die in der Gartenkultur oder der Landwirtschaft Einzug gehalten haben, wird auch auf forstlich relevante Arten (z. B. Pseudotsuga menziesii, Pinus strobus, Quercus rubra, Prunus serotina, Robinia pseudoacacia) eingegangen. Im Anschluss wird dargestellt, wie nichteinheimische Pflanzen die Tierwelt über das Angebot an Nahrung und Habitatelementen beeinflussen. Ein kleines Kapitel widmet der Autor den Neomyceten, die zu den wirtschaftlich bedeutenden Parasiten in Landwirtschaft und Gartenbau gehören. Ein Beitrag von P. Boye, in welchem Neozoen nach Artengruppen vorgestellt und Handlungsperspektiven aufgezeigt werden, ergänzt dieses Werk, das seinen Schwerpunkt bei den Pflanzen hat.

Der Band grenzt sich durch eine objektive Wertung der ökologischen und ökonomischen Auswirkungen gegen die häufig sehr emotional geführte Diskussion um den meist übertrieben eingeschätzten Einfluss fremder Floren- und Faunenelemente ab. Dies kommt auch in der vorläufigen Synthese über die Ursachen und Folgen der Ausbreitung neuer Arten zum Ausdruck. Ein äußerst umfangreiches Literaturverzeichnis (47 Seiten), das die Literatur bis 2002 berücksichtigt, und ein ausführliches Sachregister runden das Werk ab. Insgesamt bietet das Buch sehr wertvolle Informationen, die in derartigem Umfang und solcher Ausführlichkeit bisher nicht zur Verfügung standen.

Title: "Biological invasions: Neophyts and neozoans in Central Europe“.

M. LIESEBACH (Wien)

Herausgeberin: Bundesforschungsanstalt für Forst- und Holzwirtschaft: Schriftleitung: Institut für Forstgenetik und Forstpflanzenzüchtung, Siekerlandstrasse 2, D-22927 Grosshansdorf - Verlag: J. D. Sauerländer's Verlag, Finkenhofstrasse 21, D-60322 Frankfurt a. M. Anzeigenverwaltung: J. D. Sauerländer's Verlag, Frankfurt am Main.

Satz und Druck: Satz- und Grafikstudio König, Marburg — Printed in Germany. 